\section{Histological identification of Campylobacter using Gimenez technique in gastric antral mucosa}

L MCMULlEN, * M M WALKER, * L A BAIN, $\dagger$ Q N KARIM, $\dagger$ J H BARON $\ddagger$ From the Departments of *Histopathology and †Bacteriology, St Mary's Hospital, London, and the $\ddagger$ Department of Medicine, St Charles' Hospital, London

Campylobacter pyloridis, a spiral bacterium, was formally identified by Marshall and Warren in 1984. ${ }^{1}$ The association between this organism and gastrointestinal tract disease has provoked much interest, the presence of $C$ pyloridis being strongly associated with active chronic gastritis. ${ }^{23}$ In a study conducted in this laboratory on the isolation of $C$ pyloridis from upper gastrointestinal tract it was found that haematoxylin and eosin and Wartin-Starry staining were not satisfactory for the histological identification of Campylobacter sp; other staining methods were therefore investigated, and the Gimenez technique ${ }^{4}$ was found to be the most effective.

\section{Material and methods}

Thirty three patients undergoing endoscopy for investigation of upper gastrointestinal tract symptoms had biopsy specimens taken from the gastric antrum. Two adjacent areas of this region were biopsied, one placed in $10 \%$ formol saline for routine histology and one taken fresh for bacteriological studies.

\section{MICROBIOLOGY STUDIES}

Biopsy specimens were transported to the laboratory in fastidious anaerobe broth and either processed immediately or kept at $4^{\circ} \mathrm{C}$ for not longer than two hours before processing.

The specimens were cut into small pieces with sterile blades and then inoculated on to blood agar and $C$ pyloridis selective media (brain heart infusion agar with $7 \%$ horse blood, $1 \%$ IsoVitalex, vancomycin 6 $\mathrm{mg} / \mathrm{l}$, nalidixic acid $20 \mathrm{mg} / \mathrm{l}$, and amphotericin 2 $\mathrm{mg} / \mathrm{l})$. A smear was made for Gram staining.

The plates were examined after incubation for three days at $37^{\circ} \mathrm{C}$ in a microaerophilic atmosphere (Campypak). These were reincubated for up to six days, if initially negative. $C$ pyloridis was identified by typical colonial and Gram stained appearance and positive oxidase and urease tests.

The Gram stained smears were examined before the results of culture were known.
HISTOLOGY STUDIES

Specimens were fixed overnight, processed to paraffin wax, cut at $4 \mu \mathrm{m}$. The sections were stained by haematoxylin and eosin, and the Gimenez technique and examined by light microscopy without prior knowledge of microbiology results.

\section{GIMENEZ TECHNIQUE}

The technique comprises the following:

Carbol fuchsin stock RA Lamb cold acid fast bacilli stain (now stocked by BDH).

Phosphate buffer at pH 7.5 (0.1M) Mix $3.5 \mathrm{ml} \mathrm{0.1 \textrm {M }}$ monobasic sodium phosphate with $15 \cdot 50 \cdot 1 \mathrm{M}$ dibasic sodium phosphate.

Working carbol fuchsin Dilute $4 \mathrm{ml}$ stock carbol fuchsin with $10 \mathrm{ml}$ phosphate buffer. Filter immediately and again before use (stable for $\mathbf{4 8}$ hours).

Malachite green $(0.8 \%)$ Mix $0.8 \mathrm{~g}$ malachite green with $100 \mathrm{ml}$ distilled water.

Dewaxed tissue sections were taken to water and treated with working carbol fuchsin for two minutes and washed thoroughly in tap water. Malachite green was applied for 15-20 seconds. The sections were washed thoroughly in tap water. The procedure was repeated until sections became blue-green. The sections were blotted and allowed to air dry. They were cleared in xylene and mounted in dammar xylol.

\section{Results}

The Gimenez technique stained bacteria magenta against a blue-green background. The characteristic morphology of Campylobacter of a stumpy curved rod made identification simple (figure).

The table shows concordance between Gram, culture, and Gimenez staining.

\section{Discussion}

This carbol fuchsin method was first used for identification of Rickettsiae in yolk sac culture in

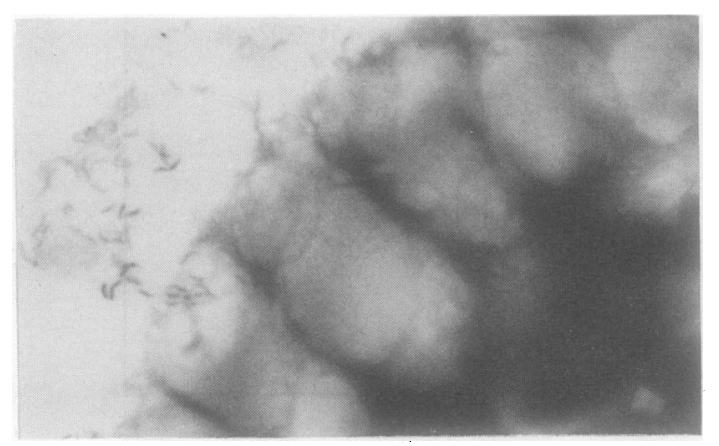

Figure Campylobacter like organisms on surface of gastric antral mucosa. 
Table

\begin{tabular}{|c|c|}
\hline $\begin{array}{l}\text { Total No of specimens examined by } \\
\text { histology and microbiology }\end{array}$ & 33 \\
\hline $\begin{array}{l}\text { Gimenez positive (light microscopy) } \\
\text { Gram positive (microbiology) } \\
\text { Culture positive (microbiology) }\end{array}$ & $\begin{array}{l}18(54 \cdot 5 \%) \\
17(51 \cdot 5 \%) \\
16(48 \%)\end{array}$ \\
\hline $\begin{array}{l}\text { Culture positive and Gimenez negative } \\
\text { Culture negative and Gimenez positive } \\
\text { Gram positive and Gimenez negative } \\
\text { Gram negative and Gimenez positive }\end{array}$ & $\begin{array}{l}3 \\
4 \\
2 \\
6\end{array}$ \\
\hline $\begin{array}{l}\text { Concordance between: } \\
\text { Gram, culture, and Gimenez } \\
\text { Culture and Gimenez } \\
\text { Gram and Gimenez }\end{array}$ & $\begin{array}{l}24(72 \%) \\
26(79 \%) \\
25(76 \%)\end{array}$ \\
\hline
\end{tabular}

1964 by Gimenez. ${ }^{4}$ Greer $^{5}$ used this method for identification of Legionella pneumophilia and found that it was successful in direct staining of lung smears in paraffin sections. This was attributed to processing, but it may be due to the site of the Legionella bacteria, which are intracellular. We found that the Gimenez technique was satisfactory both in smears and paraffin sections of necropsy lung with $L$ pneumophilia and other bacterial infections, apparently staining all types of bacteria (McMullen $\mathrm{L}$, personal observation).

The Wartin-Starry stain, a recognised technique for the identification of spiral bacteria, ${ }^{6}$ is time consuming, expensive, and technically elaborate. The results can be unreliable due to silver precipitate, and difficulty arises in the identification of separate elements.

The Gram method, although successful in direct smears of the biopsy specimen, presented problems if only a few bacteria were present. In paraffin sections the Gimenez technique was found to be superior.

To detect Campylobacter in biopsy specimens of the gastrointestinal tract both bacteriology and histology should be used. The good results, however, obtained with the Gimenez method will allow studies to be performed on retrospective series.

In studies of gastric antral mucosa we found that the Gimenez technique was quick, economical, and reliable in the detection of Campylobacter $\mathrm{sp}$ in paraffin sections.

\section{References}

1 Marshall BJ, Royce H, Annear DI, et al. Original isolation of Campylobacter pyloridis from human gastric mucosa. Microbios Letts 1984;25:83-5.

2 Goodwin CS, Armstrong JA, Marshall BJ. Campylobacter pyloridis, gastritis, and peptic ulceration. $J$ Clin Pathol 1986;39:353-65.

3 Jones DM, Lessells AM, Eldridge J. Campylobacter like organisms on the gastric mucosa: culture, histological and serological studies. J Clin Pathol 1984;37:1002-6.

4 Gimenez DF. Staining Rickettsiae in yolk sac cultures. Stain Technol 1964:39:135-40.

5 Greer PW, Chandler FW, Hicklin MD. Rapid demonstration of Legionella pneumophilia in unembedded tissue. Am J Clin Pathol 1980;73:788-90.

6 Warren JR. Unidentified curved bacilli on gastric epithelium in active chronic gastritis. Lancet 1983;i:1273-5.

Requests for reprints to: Dr M M Walker, Histopathology Department, St Mary's Hospital, Praed Street, London W2, England.

\section{Simple immunoturbidimetric method for determining urinary albumin at low concentrations using Cobas-Bio centrifugal analyser}

E M KEARNEY, J N MOUNT, G F WATTS, B M SLAVIN, P R N KIND From the Department of Chemical Pathology and Metabolic Disorders, St Thomas's Hospital, London

The finding that a raised concentration of urinary albumin, undetectable by Albustix (Ames Co Ltd, Stoke Poges, Slough, UK) - that - is, microalbuminuria predicts potentially reversible nephropathy ${ }^{1-5}$ - has led to an increasing demand from clinicians for this determination. Microalbuminuria has been strictly defined as an albumin excretion rate of $>15 \mu \mathrm{g} /$ minute (Albustix negative sample) in three major studies. ${ }^{1-3}$ Assay methods should be specific for albumin and sufficiently sensitive down to at least $3 \mathrm{mg} / \mathrm{l}$ to cover the low concentrations that may be found in cases of microalbuminuria. Existing techniques include radioimmunoassay, ${ }^{6}$ radial immunodiffusion, ${ }^{7}$ enzyme linked immunosorbent assay, ${ }^{8}$ and nephelometry. ${ }^{9}$ Because they may be time consuming, costly, or require large batch sizes, an alternative approach has been sought based on immunoturbidimetry and use of the Cobas-Bio centrifugal analyser.

\section{Material and methods}

The assays were performed using the Cobas-Bio (version 8144) centrifugal analyser (Hoffman La Roche, Basle, Switzerland). 